in cooperation with the Pennsylvania Department of Environmental Protection

\title{
Trends in Surface-Water Quality During Implementation of Best-Management Practices in Mill Creek and Muddy Run Basins, Lancaster County, Pennsylvania
}

Analyses of water samples collected over a 5-year period (1993-98) in the Mill Creek and Muddy Run Basins during implementation of agricultural best-management practices (BMP's) indicate statistically significant trends in the concentrations of several nutrient species and in nonfilterable residue (suspended solids). The strongest trends identified were those indicated by a more than 50 percent decrease in the flow-adjusted concentrations of total and dissolved phosphorus and total residue in base flow in the two streams. Analyses of stormflow samples showed a 31-percent decrease in the flow-adjusted concentration of total phosphorus in Mill Creek and a 54-percent decrease in total nonfilterable residue in Muddy Run. A 58-percent increase in the flow-adjusted concentration of total ammonia nitrogen in stormflow was found at Muddy Run.

Although the effects of a specific BMP on the indicated trends is uncertain, results of statistical trend tests of the data suggest that stream fencing, possibly in concert with other practices, such as stream crossings for livestock, barnyard runoff control, manure-storage facilities, and rotational grazing, was effective in improving water quality during base flow and probably low to moderate stormflow conditions.

Additional improvements in water quality in the Mill Creek and Muddy Run Basins seems likely as the implementation of BMP's is expected to continue. Thus, the full effect of BMP implementation in the two basins may not be observed for some time.

\section{INTRODUCTION}

The water quality of Mill Creek and Muddy Run, a tributary to Mill Creek, was the focus of a 5-year cooperative investigation involving the Pennsylvania Department of Environmental Protection (PaDEP) and the U.S. Geological Survey (USGS). Implementa- tion of agricultural best-management practices (BMP's) has been promoted in the Mill Creek Basin as part of the U.S. Department of Agriculture Pequea and Mill Creeks Hydrologic Unit Area Project to address agricultural nonpoint source (NPS) pollution. A contributing factor to NPS pollution in the Mill Creek Basin is high animal densities, particularly in areas adjacent to stream channels. Livestock commonly are pastured near streams and are allowed direct access to the stream for drinking and cooling purposes.

Although BMP's are accepted techniques to reduce NPS pollution, the long-term effects of BMP's on surface-water quality are not well documented. Moreover, the effects of BMP's on water quality when not uniformly applied are not well known on a watershed scale.

This fact sheet presents and evaluates trends in nutrient and residue (suspended solids) concentrations and summarizes nutrient and residue loads in Muddy Run and Mill Creek for the period February 1993 through September 1998 during a period of BMP implementation. Presented here are nutrient and residue data from monthly fixed-time samples and nutrient data from stormflow samples. Five-year trends in the concentrations of nutri- ents and residue in fixed-time samples and in stormflow samples are reported here.

\section{SITE DESCRIPTION}

Mill Creek Basin lies in the eastern half of Lancaster County within the larger $\left(477 \mathrm{mi}^{2}\right.$ ) (square miles) Conestoga River Basin (fig. 1). At the sampling locations, Mill Creek at Eshelman Mill Road (USGS streamgaging station no. 01576540) drains $54.2 \mathrm{mi}^{2}$, or 96 percent of the total Mill Creek Basin and Muddy Run near Weavertown (USGS streamgaging station no. 01576520 ) drains $6.68 \mathrm{mi}^{2}$, or 76 percent of the total Muddy Run Basin. The basin is predominantly underlain by fractured carbonate rock. This fractured-rock system contains numerous sinkholes and solution passages that allow surface contaminants to move quickly from the land surface to the ground water. Muddy Run Basin lies within the Mill Creek Basin and shares its agricultural and hydrologic characteristics. A typical farm in the basin averages between 50 and 60 acres and supports 50 dairy cows.

Implementation of BMP's started in 1989 and continues as of 1999. Physical BMP's used in the basins include stream fencing (fig. 2) and crossings, barnyard-runoff control,

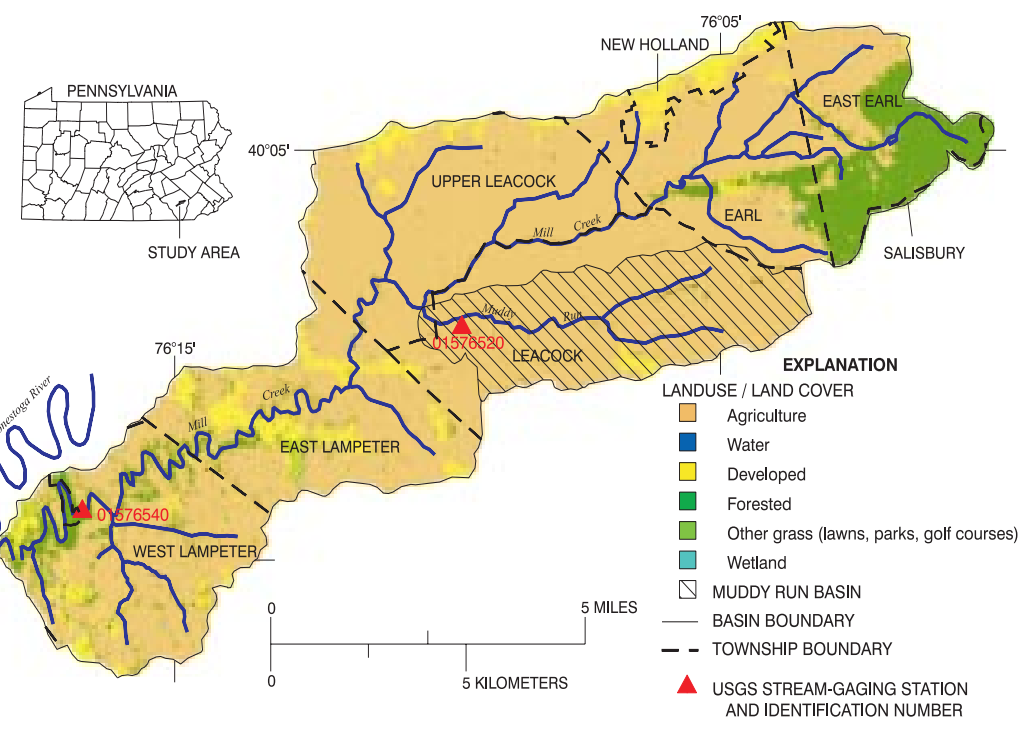

Figure 1. Location of study area. 

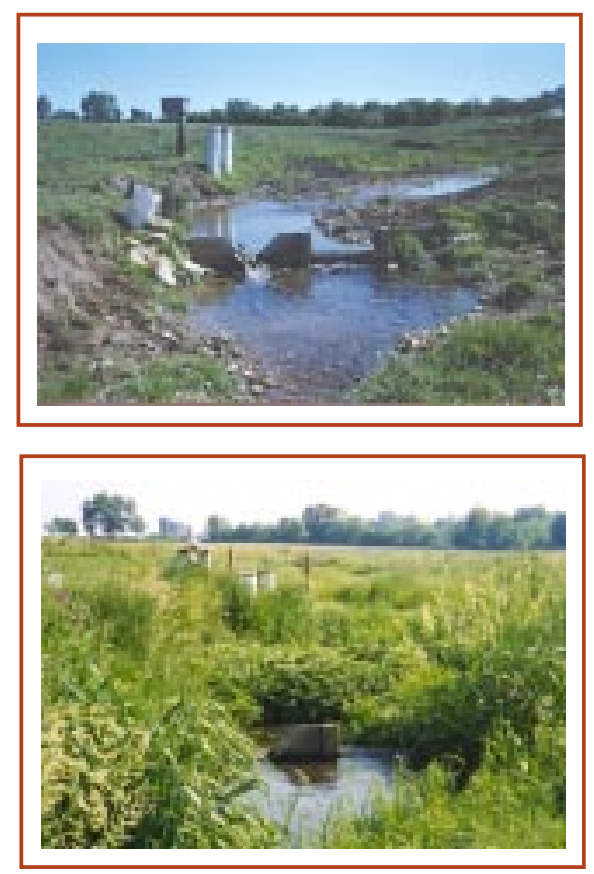

Figure 2. Typical stream fencing installation showing before (top) and after (bottom) conditions at a tributary to Mill Creek.

manure-storage facilities, and rotational grazing. As of January 1, 1998, in the Mill Creek

Basin, approximately $12-15$ of 70 total stream miles have been fenced and 50 manure storage facilities have been installed (Frank Lucas,

Natural Resources Conservation Service, written commun., 1999). About 20 percent of the farms with stream fencing installed also have implemented barnyard-runoff controls. Implementation of stream fencing is most concentrated in the Muddy Run Basin. Upstream from the Muddy Run sampling site, 16 farms or about 3.5 of 8 total stream miles have been fenced. Five manure-storage facilities have been installed in the Muddy Run Basin.

Long-term average annual precipitation at a rain gage located 2.75 miles north of the Mill Creek stream-gaging station is about 42 in. (inches). The 12-month average precipitation from October 1992 through September 1998 was 46.3 in., or 10 percent above the long-term average. The driest 12-month period was January through December 1997, when total rainfall was 29.6 in., or 30 percent below the long-term average. Mean annual streamflow from October 1992 through September 1998 was $80.5 \mathrm{ft}^{3} / \mathrm{s}$ (cubic feet per second) at the Mill Creek stream-gaging station and $9.2 \mathrm{ft}^{3} / \mathrm{s}$ at the Muddy Run stream-gaging station. A cumulative sum of departures of mean monthly streamflows from the period-ofrecord mean at the Mill Creek stream-gaging station (fig. 3) show substantial periods of below-average streamflow interspersed with periods of above-average streamflows. In response to the January through December 1997 period of reduced rainfall, a long period of below-average streamflow occurred from March 1997 through April 1998.

Pennsylvania's 303(d) list (Pennsylvania Department of Environmental Protection, 1998) records both Mill Creek and Muddy Run as having water quality impaired by agriculture. Nutrients and suspended solids are present in amounts sufficient to be detrimental to aquatic life. Counts of fecal coliform bacteria, which can pose a health hazard to water users, in the range of 270 to 190,000 colonies per $100 \mathrm{~mL}$ (milliliters) were measured in surface-water samples collected at the Muddy Run stream-gaging station during this study. Mill Creek is classified as a warm-water fishery under Pennsylvania water-quality standards (Bureau of Water Quality Management, 1994). The warm-water fishery designation is defined by the following water-quality criteria: a temperature and $\mathrm{pH}$ dependent limit on maximum total ammonia nitrogen concentration, maximum nitrite plus nitrate nitrogen concentration of $10 \mathrm{mg} / \mathrm{L}$ (milligrams per liter), and maximum fecal coliform bacteria counts from 200 to 2,000 colonies per $100 \mathrm{~mL}$.

\section{STUDY DESIGN}

The study described in this fact sheet was designed such that sufficient data were collected to permit analysis for trends in water quality over time. Water samples were collected from two sites over the period February 1993 through September 1998. Fixed-time grab samples were collected monthly by PaDEP personnel. These samples represent primarily base-flow conditions but also include stormflow conditions. Event-based stormflow samples were collected during approximately one storm per month by automatic samplers. An average of four samples was collected over the storm duration. All water samples were analyzed at PaDEP Bureau of Laboratories. Fixed-time samples were analyzed for total and dissolved fractions of ammonia nitrogen, ammonia plus organic nitrogen, nitrite plus nitrate nitrogen, and phosphorus, dissolved orthophosphorus, and

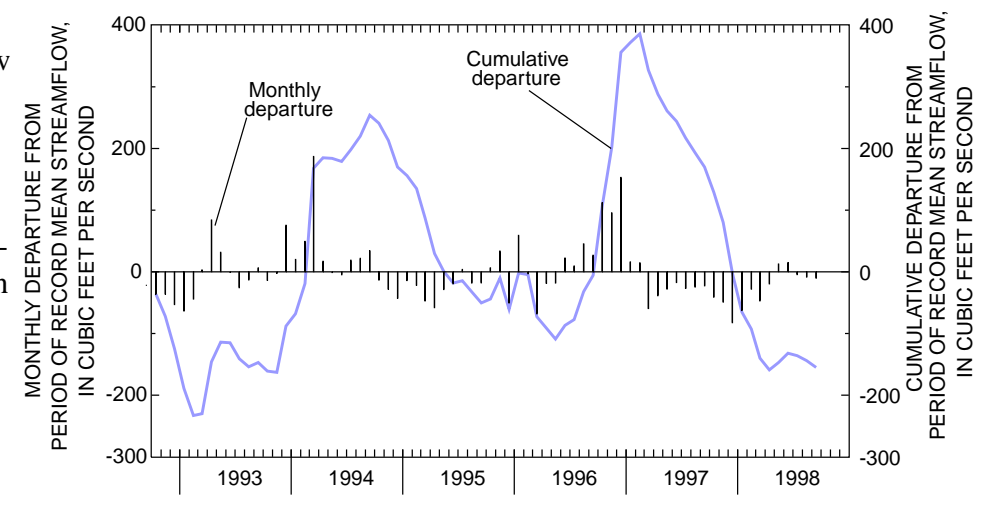

Figure 3. Monthly and cumulative departure from the period-of-record mean streamflow at Mill Creek. total nonfilterable residue, a measure of solids suspended in the sample. Stormflow samples were analyzed only for the total fractions of the constituents mentioned above. Total nitrogen was calculated as the sum of total ammonia plus organic nitrogen and total nitrite plus nitrate. If either total ammonia plus organic nitrogen or total nitrite plus nitrate concentrations were less than the laboratory reporting limit, total nitrogen was not calculated. Streamflow was measured continuously at both sites. Water-quality and streamflow data are published in U.S. Geological Survey Water-Data Reports (Durlin and Schaffstall, 1994, 1996, 1997a, 1997b, 1998, and 1999).

\section{DATA ANALYSIS}

Detailed data analysis was completed for the constituents total nitrogen, total ammonia nitrogen, total nitrite plus nitrate nitrogen, total phosphorus, dissolved phosphorus, and total nonfilterable residue. After November 1996 , total nitrogen in base flow was not calculated because of an increase in the analytical reporting limit for Kjeldahl nitrogen from 0.20 to $1.0 \mathrm{mg} / \mathrm{L}$. Kjeldahl nitrogen is a component in the calculation of total nitrogen. This increase resulted in less-than-reporting-limit values for all but a few samples after that time. Prior to data analysis, water-quality samples were separated into two groups. One group included all samples collected during low- or base-flow conditions. This group was composed entirely of fixed-time samples. The second group included samples collected during stormflow conditions. Stormflow conditions were defined as streamflow during rising, peak, and receding stages. This group was composed of event-based stormflow samples and some fixed-time samples.

Base-flow data were analyzed for trend over time by use of the Seasonal Kendall test. The Seasonal Kendall is a distribution-free test that performs satisfactorily in the presence of limited amounts of missing and censored data (Helsel and Hirsch, 1992). When flow dependence was present, trend analysis was completed on the residuals from a LOWESS smoothing procedure of the relation between constituent concentrations and discharge (Helsel and Hirsch, 1992). The level of significance $(\alpha)$ was set at 0.10 for the trend test.

\section{Stormflow data} were analyzed for trend over time with the Kendall-Thiel procedure (Helsel and Hirsch, 1992) with the level of significance set at 0.10 . 
The Kendall-Thiel analysis is similar to the Seasonal Kendall test but has no seasonal correction. Seasonality was not present or only weakly present in stormflow data. Prior to trend analysis, stormflow data were trimmed, flow corrected, and corrected for serial correlation. Trimming was done to prevent trend bias because of the smaller range of streamflows sampled during the March 1997 through April 1998 period. Flow correction was accomplished by performing a linear regression of log transformed concentration and streamflow data. Strong serial correlation in the data was due to stormflow samples during an individual storm being closely spaced in time. Serial correlation, when present, produces erroneous probability values for statistical trend tests. Serial correlation was eliminated or reduced by calculating a mean daily concentration for days with multiple samples. Sample concentrations were flowadjusted prior to determining the mean daily concentration.

Loads and yields of water-quality constituents were calculated with the USGS Minimum Variance Unbiased Estimator model (MVUE) (Cohn and others, 1989). The MVUE is a log-linear model used to estimate loads of nutrients and total suspended solids entering the Chesapeake Bay (Langland and others, 1998). Because the MVUE calculates annual loads, the months October 1992 through January 1993 were included to allow estimation of the October 1992 to October 1993 loads. Total nitrogen loads for the period beginning December 1996 through the end of the study were calculated using one-half the reporting-limit value $(0.5 \mathrm{mg} / \mathrm{L})$ for concentrations of total ammonia plus organic nitrogen less than the reporting limit.

\section{Water Quality}

Base-flow nitrogen data (fig. 4A) showed substantial variation during the study period. Most variation resulted from strong seasonal
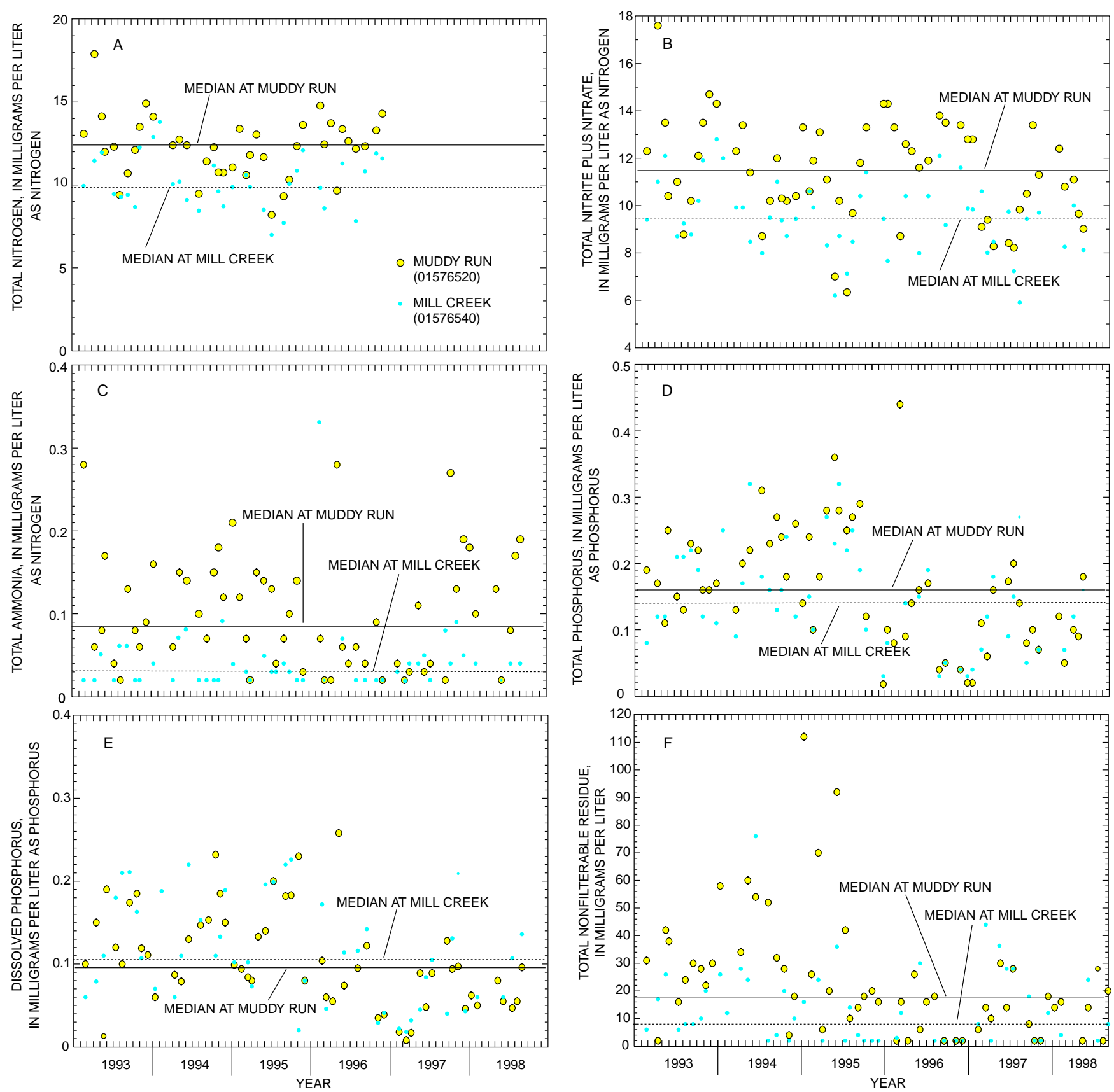

Figure 4. Time series graphs of nutrient and residue concentrations in base-flow samples of Muddy Run and Mill Creek from February 1993 through September 1998. 
fluctuation, particularly in total nitrite plus nitrate nitrogen. A noticeable short-term increase in median concentrations of nitrite plus nitrate nitrogen in Muddy Run occurred during 1996 (fig. 4B). Total nitrite plus nitrate was the predominant nitrogen species. About 95 percent of the total nitrogen was nitrite plus nitrate nitrogen. Seasonality was not observed in total ammonia nitrogen (fig. 4C). Concentrations of total ammonia nitrogen were consistently greater in Muddy Run. The median concentration for the period of record was about three times that for Mill Creek. The warmwater fisheries criteria of $10 \mathrm{mg} / \mathrm{L}$ maximum of total nitrite plus nitrate nitrogen was exceeded in 76 percent of the base-flow samples from Muddy Run and 31 percent of the samples from Mill Creek.

A time-series graph of total phosphorus in base flow (fig. 4D) shows substantial change over the study period. Total phosphorus in base flow appears to be increasing through 1995 then decreases abruptly for the remainder of the study period. This step decrease occurred at both sites. Concentrations of dissolved phosphorus (fig. 4E) also showed the step decrease. However, the step was not discernible in concentrations of dissolved orthophosphate (not shown). Total phosphorus tended to be greater in Mill Creek but the pattern was not consistent. Median concentrations of total phosphorus in Muddy Run and Mill Creek were similar.

Concentrations of total nonfilterable residue in base flow showed distinct differences between the Muddy Run and Mill Creek sites (fig. 4F). Total nonfilterable residue in Muddy Run exhibited a pattern similar to that seen in total phosphorus. Prior to 1996, concentrations tended to be of greater range and magnitude. Concentrations of total nonfilterable residue in Mill Creek, however, remained constant in range and magnitude throughout the study period. The median concentration of total nonfilterable residue in Muddy Run was twice that in Mill Creek.

Median concentrations of nutrients in stormflow samples were generally greater in Muddy Run than in Mill Creek (fig. 5). Annual median concentrations of total nitrogen (fig. 5A) and total ammonia nitrogen (fig. 5B) were always greater in Muddy Run, whereas median concentrations of total nitrite plus nitrate nitrogen (fig. 5C) were similar. Median concentrations of total phosphorus (fig. 5D) also were greater in Muddy Run. Median concentrations of total nonfilterable residue (fig. 5E) in stormflow
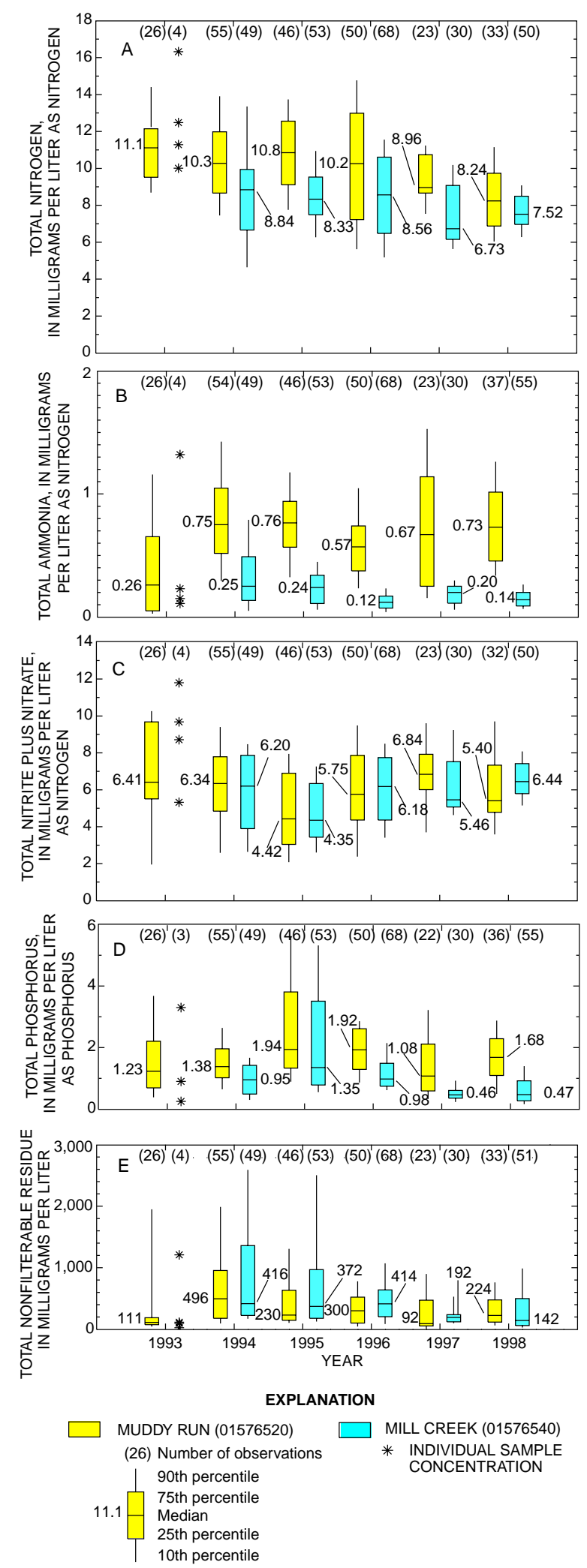

Figure 5. Summary of concentrations of nutrient and residue in stormflow samples at Muddy Run and Mill Creek from October 1992 through September 1998. were not consistently greater at either site. Stormflow samples represented streamflows ranging from 33 to $3,200 \mathrm{ft}^{3} / \mathrm{s}$ at Mill Creek and from 3 to $564 \mathrm{ft}^{3} / \mathrm{s}$ at Muddy Run.

The range of nutrient concentrations in stormflow samples in any given year tended to reflect the range of streamflows sampled, except for the concentrations of total ammonia nitrogen in Muddy Run. The greatest range of streamflows was sampled in the middle third of the study period and the smallest range was sampled during the final third of the study period. The range of concentrations of total ammonia nitrogen in Muddy Run was greater in the final third of the study period.

\section{Trends in Nutrient and Residue Concentrations}

Both seasonality and flow dependence must be considered when testing for trend over time. Seasonality, if not corrected for, generally increases variance in the data and thus reduces the power of a test to detect a trend. Flow dependence also can alter data variance and may result in a false trend.

Seasonality was evident in a number of constituents during base-flow conditions. Seasonality was most pronounced in total nitrite plus nitrate nitrogen; winter to summer variation in total nitrite plus nitrate nitrogen commonly exceeded 100 percent. Concentrations were greatest in winter and least in mid to late summer. Seasonality also was detected in total and dissolved phosphorus although less well defined and in opposite phase to total nitrite plus nitrate. Concentrations were greatest in late summer to fall and least in winter.

Most constituents were flow dependent. Two examples of flow dependency are shown in figure 6. In Mill Creek, the concentration of total nitrite plus nitrate nitrogen tended to increase with increasing base flow up to about $70 \mathrm{ft}^{3} / \mathrm{s}$, above which the concentration remains somewhat constant. In Muddy Run, concentrations of total phosphorus decrease with increasing base flow. Constituents that were flow dependent were flow adjusted as indicated in table 1.

Muddy Run and Mill Creek had significant downward trends in constituent concentrations in base flow over the study period (table 1). Proportionally, the largest decreases were in Muddy Run. Total and dissolved phosphorus decreased 68 and 67 percent, respectively, over the study period. Total nonfilterable residue decreased 85 percent. Muddy Run had no significant trend in nitrogen. At Mill Creek, trends were similar. Total and dissolved phosphorus concentrations decreased 60 and 54 percent, respectively, and total nonfilterable residue decreased 58 percent. In addition, a 13-percent decrease 

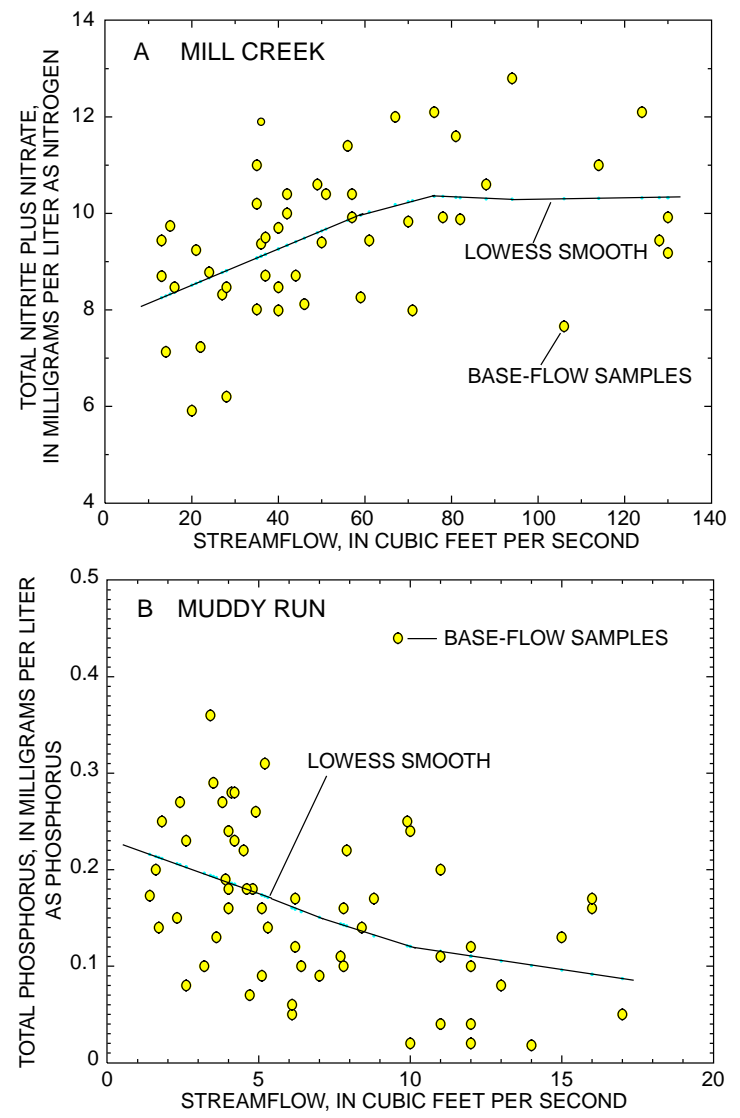

Figure 6. Relation between base-flow discharge and nutrient concentrations at Mill Creek (A) and Muddy Run (B).

in total nitrite plus nitrate nitrogen was detected at Mill Creek.

The downward trend in concentrations of total nitrite plus nitrate resulted in a decrease in the number of times the $10-\mathrm{mg} / \mathrm{L}$ warmwater fishery criteria was exceeded. In the first 12 months of the study, the $10-\mathrm{mg} / \mathrm{L}$ criterion was exceeded at Mill Creek in 6 of 10 samples, and in the last 12 months, there were no exceedences in 8 samples. At Muddy Run, the $10-\mathrm{mg} / \mathrm{L}$ criterion was exceeded in 10 of 11 samples in the first 12 months and in 6 of 10 samples in the last 12 months.

Trends detected in base-flow water quality in Mill Creek and Muddy Run cannot be linked specifically to BMP implementation in the basins. Because variables such as climate and land-use patterns also can affect water quality, the effect that BMP's, and to a greater degree, a specific BMP, have on these trends is uncertain. However, some general observations can be made. Reduction of sediment (represented by residue concentrations) transport in a stream is listed as a potential benefit of stream fencing, the BMP most widely applied in the study area. Because of the strong association of phosphorus with sediment, a decrease in sediment delivered to and transported by a stream will commonly result in a simultaneous decrease in concentrations of phosphorus. Results of the trend tests support the sediment (residue)phosphorus association and suggest stream fencing has been effective in improving water quality. Moreover, an incremental if not uniform increase in the length of stream fenced over the study period suggests the trends should be gradual, and decreases in mean concentrations will be distributed over the study period. However, concentrations of total and dissolved phosphorus and total nonfilterable residue decreased abruptly in late 1995 . The decrease was detected at both sites and was coincident with an increase in concentrations of total nitrite plus nitrate nitrogen. This opposite-in-phase behavior of phosphorus and nitrite plus nitrate is more typical of seasonal variation. On the basis of the limited available data, it is not known whether stream fencing, other BMP's, climate, or other unknown change caused the rapid decreases in mean concentrations of total and dissolved phosphorus and total nonfilterable residue.

Few significant trends were detected in stormflow (table 1). At Muddy Run, total ammonia nitrogen increased 58 percent and total nonfilterable residue decreased 54 percent.
One significant trend was found at Mill Creek; total phosphorus decreased 31 percent over the study period. Stormflow trends were not consistent across sites.

Detecting and interpreting trends in stormflow data is more difficult than in baseflow data. Stormflow water quality characteristically has greater variation than does baseflow water quality. Storm intensity, duration, time of occurrence, areal coverage, and antecedent land-surface conditions are some of the variables that combine somewhat randomly to determine water quality during a given storm. This randomness adds difficulty to the determination of whether the data exhibit real trends or artifacts of the above variables. If stream fencing is the source of the downward trends in total phosphorus and total nonfilterable residue in base flow, stream fencing can be expected to have an effect on stormflow water quality, particularly at lower stormflows. At higher stormflows, however, stream fencing is likely to be less effective because of complete submergence of any established vegetation within the fenced area.

Water quality has improved in the Mill Creek and Muddy Run Basins since February 1993. Of 10 significant trends, 9 were downward, indicating improved water quality. With the implementation of BMP's continuing beyond the completion of this study, additional improvements in water quality seem likely. The maximum improvement in water quality will probably not be realized, however, until some time after BMP implementation reaches its maximum.

Table 1. Trends in concentrations of nutrients and nonfilterable residue in Muddy Run and Mill Creek from February 1993 through September 1998

[up, upward; down, downward; --, no trend; n, number of sample]

\begin{tabular}{|c|c|c|c|c|c|c|c|c|c|c|}
\hline \multirow[b]{2}{*}{ Constituent } & \multicolumn{5}{|c|}{ Base flow } & \multicolumn{5}{|c|}{ Stormflow } \\
\hline & $\mathrm{n}$ & $\begin{array}{c}\text { Flow } \\
\text { adjust- } \\
\text { ment }\end{array}$ & Trend & p-value & $\begin{array}{l}\text { Trend } \\
\text { slope }^{1}\end{array}$ & $\mathrm{n}$ & $\begin{array}{c}\text { Flow } \\
\text { adjust- } \\
\text { ment }\end{array}$ & Trend & $\mathrm{p}$-value & $\begin{array}{l}\text { Trend } \\
\text { slope }^{1}\end{array}$ \\
\hline \multicolumn{11}{|c|}{ Muddy Run (01576520) } \\
\hline Total nitrogen & 39 & $\bar{Y}$ & -- & 0.896 & -- & 54 & $\bar{Y}$ & -- & 0.921 & -- \\
\hline $\begin{array}{l}\text { Total ammonia } \\
\text { nitrogen }\end{array}$ & 58 & Y & -- & .145 & -- & 75 & Y & up & .094 & +0.05 \\
\hline $\begin{array}{l}\text { Total nitrite plus } \\
\text { nitrate nitrogen }\end{array}$ & 58 & $\mathrm{Y}$ & -- & .167 & -- & 74 & Y & -- & .660 & -- \\
\hline Total phosphorus & 58 & Y & down & $<.001$ & -0.03 & 75 & $\mathrm{Y}$ & -- & .861 & -- \\
\hline $\begin{array}{l}\text { Dissolved } \\
\text { phosphorus }\end{array}$ & 56 & $\mathrm{Y}$ & down & $<.001$ & -.02 & -- & -- & -- & -- & -- \\
\hline $\begin{array}{l}\text { Total non- } \\
\text { filterable residue }\end{array}$ & 58 & $\mathrm{~N}$ & down & .002 & -4.67 & 75 & $\mathrm{Y}$ & down & .069 & -30.1 \\
\hline \multicolumn{11}{|c|}{ Mill Creek (01576540) } \\
\hline Total nitrogen & 32 & $\mathrm{Y}$ & -- & .148 & -- & 51 & $\mathrm{Y}$ & -- & .556 & -- \\
\hline $\begin{array}{l}\text { Total ammonia } \\
\text { nitrogen }\end{array}$ & 48 & $\mathrm{~N}$ & -- & .765 & -- & 78 & $\mathrm{Y}$ & -- & .229 & -- \\
\hline $\begin{array}{l}\text { Total nitrite plus } \\
\text { nitrate nitrogen }\end{array}$ & 49 & $\mathrm{Y}$ & down & .096 & -.22 & 76 & $Y$ & -- & .576 & -- \\
\hline Total phosphorus & 49 & $Y$ & down & .011 & -.02 & 77 & $\mathrm{Y}$ & down & .078 & -.05 \\
\hline $\begin{array}{l}\text { Dissolved } \\
\text { phosphorus }\end{array}$ & 47 & $\mathrm{Y}$ & down & $<.001$ & -.01 & -- & -- & -- & -- & -- \\
\hline $\begin{array}{l}\text { Total non- } \\
\text { filterable residue }\end{array}$ & 49 & $\mathrm{~N}$ & down & .061 & -1.17 & 76 & $\mathrm{Y}$ & -- & .966 & \\
\hline
\end{tabular}

${ }^{1}$ Trend slope expressed as milligrams per liter per year. Slope reported only if the $p$-value $\leq 0.10$. 


\section{Loads and Yields}

Estimates of constituent loads were calculated for the period October 1, 1992, through September 30, 1998 (table 2). Estimated loads should be evaluated with respect to the reported errors. In a number of cases, the percentage error is such that the lower bound of the load estimate is zero.

Table 2. Constituent loads and yields for the period October 1, 1992, through September 30 , 1998

\begin{tabular}{|c|c|c|c|}
\hline Constituent & $\begin{array}{l}\text { Load } \\
\text { (in tons) }\end{array}$ & $\begin{array}{l}\text { Mean } \\
\text { annual } \\
\text { yield } \\
\text { (in } \\
\text { pounds/ } \\
\text { acre) }\end{array}$ & $\begin{array}{l}\text { Error } \\
\text { (in } \\
\text { percent) }\end{array}$ \\
\hline \multicolumn{4}{|c|}{ Muddy Run (01576520) } \\
\hline Total nitrogen & 592 & 46.2 & 3.4 \\
\hline Total ammonia & 31.9 & 2.48 & 20 \\
\hline $\begin{array}{l}\text { Total nitrite } \\
\text { plus nitrate } \\
\text { nitrogen }\end{array}$ & 441 & 34.3 & 5.7 \\
\hline $\begin{array}{l}\text { Total } \\
\text { phosphorus }\end{array}$ & 88.7 & 6.92 & 28 \\
\hline $\begin{array}{l}\text { Dissolved } \\
\text { phosphorus }\end{array}$ & 12.8 & 1.00 & 46 \\
\hline $\begin{array}{l}\text { Total non- } \\
\text { filterable } \\
\text { residue }\end{array}$ & 38,700 & 3,020 & 87 \\
\hline \multicolumn{4}{|c|}{ Mill Creek (01576540) } \\
\hline Total nitrogen & 4,620 & 44.3 & 4.2 \\
\hline Total ammonia & 91.9 & .89 & 18 \\
\hline $\begin{array}{l}\text { Total nitrite } \\
\text { plus nitrate } \\
\text { nitrogen }\end{array}$ & 3,360 & 32.2 & 3.8 \\
\hline $\begin{array}{l}\text { Total } \\
\text { phosphorus }\end{array}$ & 524 & 5.03 & 27 \\
\hline $\begin{array}{l}\text { Dissolved } \\
\text { phosphorus }\end{array}$ & 120 & 1.15 & 39 \\
\hline $\begin{array}{l}\text { Total non- } \\
\text { filterable } \\
\text { residue }\end{array}$ & 385,000 & 3,700 & 70 \\
\hline
\end{tabular}

Comparison of the mean annual yields, in pounds per acre, for Muddy Run and Mill Creek (table 2) shows them to be similar except for total ammonia. Total ammonia yield at Mill Creek is roughly one-third the yield at Muddy Run. A comparison of mean annual total nitrogen, total nitrite plus nitrate nitrogen, and total phosphorus yields for Muddy Run, Mill Creek, and for the Conestoga River at Conestoga (stream-gaging station no. 01576754) (fig. 7) shows virtually the same yields for all three sites. The Conestoga River at Conestoga was ranked first in total nitrogen and total phosphorus yields among 54 and 75 nontidal surface-water sites, respectively, throughout the Chesapeake Bay Basin (Langland and others, 1998). Mean annual yields for the Conestoga River were calculated for the period 1994 through 1996 by use of the MVUE. The similarity in yields of NPS contaminants from Muddy Run and Mill Creek Basins to yields from the Conestoga River

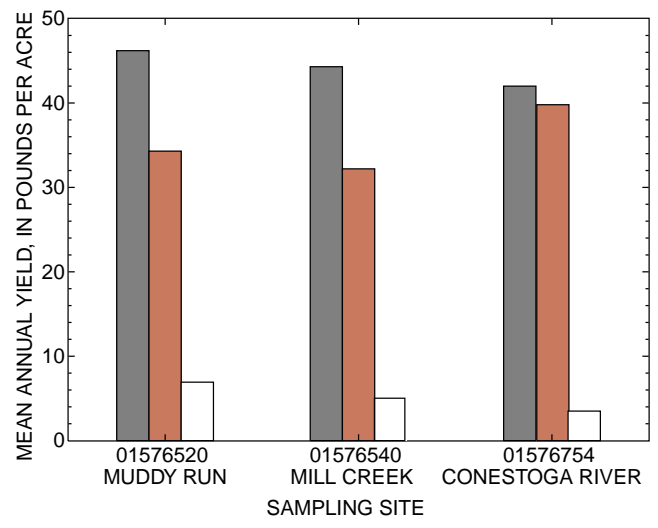

FOR ADDITIONAL INFORMATION

For information on USGS programs and activities in Pennsylvania, please visit our web site at

http://pa. water.usgs.gov

or contact

District Chief

USGS, WRD

840 Market Street

Lemoyne, PA 17043-1584

Phone: 717.730 .6900

Fax: 717.730.6997

email: dc_pa@usgs.gov

Additional earth science information can be found by accessing the USGS Home Page at

Figure 7. Mean annual yields of nutrients at Muddy Run and Mill Creek from October 1, 1992, through September 30, 1998, and the Conestoga River from January 1, 1994, through December 1996.

http://www.usgs.gov

For information on all USGS products and services, call

Basin suggests that water-quality improvements resulting from successful BMP implementation in these smaller basins could be extended to the much larger Conestoga River Basin, given equivalent BMP implementation.

\section{-Edward H. Koerkle}

1.888.ASK.USGS

Fax: 703.648.5548

email: esic@usgs.gov

Additional information about other

Federal, State, and Citizen Programs can be found by accessing the Chesapeake Bay Information Network Home Page at

http://www.chesapeake.org

\section{REFERENCES CITED}

Bureau of Water Quality Management, Pennsylvania Department of Environmental Resources, 1994, Chapter 93 . Water quality standards: Pennsylvania code, Title 25. Environmental resources, Commonwealth of Pa., $212 \mathrm{p}$.

Cohn, T.A., DeLong, L.L., Gilroy, E.J., Hirsch, R.M., and Wells, R.M., 1989, Estimating constituent loads: Water Resources Research, v. 25, no. 5, p. 937-942.

Durlin, R.R., and Schaffstall, W.P., 1994, Water resources data, Pennsylvania, water year 1993, Susquehanna and Potomac River Basins: U.S. Geological Survey Water-Data Report PA-93-2, $361 \mathrm{p}$.

1996, Water resources data, Pennsylvania, water year 1994, Susquehanna and Potomac River Basins: U.S. Geological Survey WaterData Report PA-94-2, 418 p.

1997a, Water resources data, Pennsylvania, water year 1995, Susquehanna and Potomac River Basins: U.S. Geological Survey WaterData Report PA-95-2, 518 p.

1997b, Water resources data, Pennsylvania, water year 1996, Susquehanna and Potomac River Basins: U.S. Geological Survey WaterData Report PA-96-2, 280 p.
1998, Water resources data, Pennsylvania, water year 1997, Susquehanna and Potomac River Basins: U.S. Geological Survey WaterData Report PA-97-2, 439 p.

1999, Water resources data, Pennsylvania, water year 1998, Susquehanna and Potomac River Basins: U.S. Geological Survey WaterData Report PA-98-2, 456 p.

Helsel, D.R., and Hirsch, R.M., 1992, Statistical methods in water resources: Amsterdam, Netherlands, Elsevier Science Publishers, Studies in Environmental Science, v. 49, 522 p.

Langland, M.J., Edwards, R.E., and Darrell, L.C., 1998, Status yields and trends of nutrients and sediment and methods of analysis for the nontidal data-collection programs, Chesapeake Bay Basin, 1985-96: U.S. Geological Survey Open-File Report 98-17, 60 p.

Pennsylvania Department of Environmental Protection, 1998, Commonwealth of Pennsylvania Section 303(d) list 1998, final: Pennsylvania Department of Environmental Protection, Bureau of Watershed Conservation, accessed November 1, 1999, at URL http:// www.dep.state.pa.us/dep/deputate/watermgt/ wc/Subjects/WQStandards/ 303_water98_narr.htm 